\title{
IMPACT TOUGHNESS OF LASER-WELDED BUTT JOINTS OF THE NEW STEEL GRADE STRENX 1100MC
}

\author{
UDARNA ŽILAVOST LASERSKO VARJENIH ČELNIH SPOJEV PRI \\ NOVOLEGIRANEM JEKLU STRENX 1100MC
}

\author{
Agnieszka Kurc-Lisiecka \\ University of Dąbrowa Górnicza, Rail Transport Department, Cieplaka 1C, 41-300 Dąbrowa Górnicza, Poland \\ a.kurc@wp.pl \\ Prejem rokopisa - received: 2016-07-31; sprejem za objavo - accepted for publication: 2016-11-08
}

doi:10.17222/mit.2016.234 \begin{abstract}
The detailed influence of the energy input of autogenous laser welding by means of a modern solid-state disk laser on the
structure of the weld metal, the heat-affected zone and the mechanical properties of 5.0-mm-thick butt joints of STRENX $1100 \mathrm{MC}$ was studied. Laser-welding trails were conducted over a wide range of energy inputs, from approximately 100 up to $400 \mathrm{~J} / \mathrm{mm}$. The studies showed no tendency for the cracking of butt joints, despite the low energy inputs of the welding. However, a significant decrease in the hardness was revealed in the heat-affected zone. The static tensile strength was found to be slightly lower (by approx. $8 \%$ ) compared to the tensile strength of the base material. There was also a strong relationship between the impact toughness of the test joints and the energy input of the laser welding. However, the impact toughness of the laser-welded joints was significantly lower than that of the base material. This article attempts to explain the drop in the toughness and the static tensile strength with respect to the structural transformations of the weld metal and the heat-affected zone, depending on the welding parameters, especially the energy input, and thus the heating conditions of the welding.

Keywords: laser welding, high-strength steel, toughness, butt joints, disk laser
\end{abstract}

Preiskovan je bil podroben vpliv dovedene energije avtogenega laserskega varjenja s pomočjo laserja na SSD-ju na strukturo varjenega jekla, na toplotno vplivano področje varjenja (angl. HAZ) in na 5.0-mm debele čelne spoje pri jeklu STRENX $1100 \mathrm{MC}$. Lasersko varjene poteze so bile izvedene v širokem razponu energijskih vložkov, od približno $100 \mathrm{~J} / \mathrm{mm} \mathrm{do} 400 \mathrm{~J} / \mathrm{mm}$. Studije so pokazale, da čelni spoji ne pokajo kljub nizko-energijskemu dovajanju energije pri varjenju. Vendar pa se je pokazalao znatno znižanje mikrotrdote v toplotno vplivani coni. Ugotovljeno je bilo, da je statična natezna trdnost nekoliko nižja (ca. $8 \%$ ) v primerjavi z natezno trdnostjo osnovnega materiala. Ugotovljena je bila tudi močna povezava med udarno žilavostjo testnih spojev in dovedeno energijo med laserskim varjenjem. Kakorkoli, udarna žilavost lasersko varjenih spojev je bila občutno nižja kot pri osnovnem materialu. Članek poizkuša razložiti padec žilavosti in statično natezno trdnost glede na strukturne transformacije varjenega jekla in na toplotno prizadeta območja, odvisno od varilnih parametrov, zlasti dovajanja energije in s tem toplotnih pogojev varjenja.

Ključne besede: lasersko varjenje, visokotrdno jeklo, trdnost, čelni spoji, laserski disk

\section{INTRODUCTION}

A continuous and dynamic development in the field of steel metallurgy, plastic forming and heat treatment leads not only to an improvement of mechanical properties and overall performance of modern structural steels, but also to an implementation of completely new grades of advanced high-strength steels (AHSS) and super high-strength steels (SHSS), such as STRENX 1100MC. ${ }^{1-7}$ This new steel grade shows the strength and yield point $(1100 \mathrm{MPa})$ of quenched and tempered low-alloy steels, while being a low-carbon equivalent at a level similar to the typical thermomechanically rolled, fine-grained, microalloyed steels. ${ }^{8-11}$ To be able to use such high strength and performance of this steel grade in practice, it is necessary to provide at least similar properties of the welded joints. ${ }^{1-8,12-15}$ However, there is currently no method of conventional arc welding that could provide such high mechanical properties of welded joints. ${ }^{16-22}$ Conventional welding technologies such as manual metal arc welding (MMAW), gas metal arc weld- ing (GMAW) or submerged arc welding (SMAW) are cannot provide satisfactory properties of welded joints, especially in the case of steel grades having the yield point above the level of $900 \mathrm{MPa}$. That is why the leading steel manufacturers around the world continue to develop new steel grades, new solutions in the production process, the methods of forming properties, while paying the greatest attention to the importance of improving the weldability of modern high-strength and ultra-high-strength steels.

Therefore, the global industry's attention is focused on laser-welding technologies, which provide a much wider technological capabilities and flexibilities. 1,6,23-25 Laser-beam welding (LBW) is one of the most advanced welding technologies. ${ }^{1,6,26}$ Its mechanisms of material heating, melting, and subsequent solidification and weld forming are significantly different, compared to conventional arc-welding processes. ${ }^{6,22-28}$ Moreover, the intensity of laser-beam heating, the mechanism of surface melting, the penetration depth, the shaping of the fusion zone, the width/depth ratio and the volume of the weld 
pool depend on laser-beam characteristics and also on processing parameters. ${ }^{1,6}$ However, so far there has been no information about the laser welding of the new steel grade STRENX 1100MC. Therefore, the author undertook a research in the field of autogenous laser welding of the new steel grade STRENX 1100MC, recently introduced into the global industry. The aim of the work is to study the microstructure, morphology and mechanical properties of butt joints of STRENX 1100MC, 5.0 mm thick, and welded with a modern solid-state Yb:YAG disk laser.

\section{EXPERIMENTAL PART}

\subsection{Material}

The $5.0 \mathrm{~mm}$ thick plates of steel grade STRENX $1100 \mathrm{MC}$, currently commercially available, were chosen for laser-welding tests. However, the steel plates were delivered by the WIELTON Company directly from the Swedish steelwork as experimental plates (melt).

The new grade of steel STRENX1100 MC is classified by the manufacturer as thermomechanically rolled fine-grained microalloyed steel. However, the mechanical properties of this steel go far beyond the steels specified in the standard for thermomechanically rolled steels (EN 10149-2). Additionally, details of the manufacturing process of the new steel grade are undisclosed by the manufacturer. The investigated steel with a nominal chemical composition of $0.16 \% \mathrm{C}$, $0.30 \% \mathrm{Si}, 1.3 \% \mathrm{Mn}, 0.018 \% \mathrm{Al}$, the sum of $\mathrm{Nb}+\mathrm{Ti}+\mathrm{V}$ with a maximum of $0.18 \%$ in mass fractions and balance $\mathrm{Fe}$ has the minimum yield strength of $1100 \mathrm{MPa}$, a typical tensile strength of 1200-1460 MPa and an elongation of A5 min $6 \%$ for a sheet thickness $\geq 3 \mathrm{~mm}$. Specimens for the laser-welding test were cut from a 5.0-mm-thick steel plate into coupons with dimensions of $(100.0 \times$ $100.0) \mathrm{mm}$ by means of a $2 \mathrm{D}$ laser cutting machine with a $\mathrm{CO}_{2}$ generator. Surfaces to be welded were sand blasted and then cleaned with acetone.

\subsection{Laser-welding procedure}

The trials of welding were performed by means of a solid-state Yb:YAG disk laser emitted in the continuous-wave (cw) mode at a $1.03 \mu \mathrm{m}$ wavelength with the maximum output power of $3.3 \mathrm{~kW}$. The laser beam was focused on a diameter of $200 \mu \mathrm{m}$. First, the bead-onplate welds were produced at the maximum output laser power of $3.3 \mathrm{~kW}$ and different welding speeds, as shown in Table 1. The bead-on-plate welds were produced to simulate the process of welding autogenous butt joints and to investigate the influence of the welding parameters on the penetration depth and weld shape. Based on the bead-on-plate welding trials, the optimum parameters for butt-joint welding were selected. A proper and full penetration of the 5.0-mm-thick steel plate, a proper shape of the weld with narrow face and root, and a narrow HAZ were chosen as criterions for the selection of the welding parameters for the test butt joints.

Table 1: Parameters of bead-on-plate laser welding of 5.0-mm-thick plates of STRENX 1100MC steel, using the Yb:YAG disk laser

\begin{tabular}{|c|c|c|c|c|}
\hline $\begin{array}{c}\text { Bead } \\
\text { (joint) }\end{array}$ & $\begin{array}{c}\text { Welding speed, } \\
\mathrm{m} / \mathrm{min}\end{array}$ & $\begin{array}{c}\text { Laser } \\
\text { power } \\
(\mathrm{W})\end{array}$ & $\begin{array}{c}\text { Energy } \\
\text { input } \\
(\mathrm{J} / \mathrm{mm})\end{array}$ & Remarks \\
\hline 1 & 2.0 & 3.3 & 99 & LP, UF, S \\
\hline $2(\mathrm{~A})$ & 1.5 & 3.3 & 132 & $\begin{array}{c}\text { HF, ERR, SP, } \\
\text { FP }\end{array}$ \\
\hline $3(\mathrm{~B})$ & 1.0 & 3.3 & 198 & S, ERR, HF, FP \\
\hline 4 & 0.5 & 3.3 & 396 & $\begin{array}{c}\text { UF, S, FP, SP, } \\
\text { HF, ERR }\end{array}$ \\
\hline
\end{tabular}

Other welding parameters: nominal beam-spot diameter: $200.0 \mu \mathrm{m}$, shielding-nozzle diameter: $8.0 \mathrm{~mm}$, shielding gas: Ar $(99.999 \%)$, gas feed rate on the top surface (face of a weld): $15.0 \mathrm{~L} / \mathrm{min}$, quality assessment of the welds: LP - lack of penetration, FP - full penetration, UF - undercut of the weld face, S - spatter, HF - hollow face, ERR - excessive root reinforcement, ER - excessive face reinforcement, $\mathrm{SP}$ - single pore

A further analysis showed that the bead-on-plate weld produced at a welding speed of $0.5 \mathrm{~m} / \mathrm{min}$ (thus, the heat input was almost $400 \mathrm{~J} / \mathrm{mm}$ ) was extremely wide and overheated. On the other hand, the bead-on-plate weld produced at the maximum welding speed was characterized by an uneven width of the weld root at the limit of penetration. Therefore, the test butt joints used for a detailed analysis of the microstructure and for mechanical examinations were produced at the maximum laser power of $3.3 \mathrm{~kW}$ and welding speeds of $1.0 \mathrm{~m} / \mathrm{min}$ and $1.5 \mathrm{~m} / \mathrm{min}$, respectively. Detailed parameters and technological conditions of autogenous laser welding are given in Table 1. The specimens to be welded were mounted to a clamping device to protect them against distortions. The weld pool was protected by an argon flow via four cylindrical nozzles with a diameter of 8.0 $\mathrm{mm}$ and set at an angle of $45^{\circ}$ to the joint surface. The flow of argon was kept at $15 \mathrm{~L} / \mathrm{min}$. The laser beam with a beam spot diameter of $200.0 \mu \mathrm{m}$ was focused on the top surfaces of the specimens to be welded.

\subsection{Characterisation}

When the laser-welding tests were completed, visual inspections (VT) were performed according to the procedure of quality control in welding. Next, metallographic and mechanical examinations were done. An examination of the structure was carried out by means of optical microscopes $(\mathrm{OM})$ and a scanning electron microscope (SEM). The chemical composition of the base metal was determined using a glow discharge spectrometer (GDS). The mechanical tests included a technological bending test according to the PN-EN ISO 5173 standard, a static tensile test according to the PN-EN ISO 4136 standard and the Charpy V-notch test according to the PN-EN ISO 14556 standard. From each test joint, three samples were taken for the bending test, tensile test and toughness test. 
Therefore, the mean values given are the results of the mechanical tests and examinations.

The Vickers microhardness was measured along the symmetry axes of the butt joints, and the microhardness profiles were determined. The microhardness values in specific regions of the surface layers were correlated with the structures.

\section{RESULTS AND DISCUSSION}

\subsection{Macrostructure characterisation}

Based on the preliminary tests of bead-on-plate laser welding, the energy input of approx. $100 \mathrm{~J} / \mathrm{mm}$ (a laser power of $3.3 \mathrm{~kW}$, a welding speed of $2.0 \mathrm{~m} / \mathrm{min}$ ) required for a full penetration of the 5.0-mm-thick plate of the STRENX 1100 MC steel was determined. The fully penetrated bead-on-plate weld was produced at the maximum output power of $3.3 \mathrm{~kW}$ of the applied disk laser TRUMPF TruDisk 3302 and a welding speed of $2.0 \mathrm{~m} / \mathrm{min}$. The face (top surface) width of the bead-onplate weld produced at the minimum energy input was approx. $1.45 \mathrm{~mm}$, while the root (back side) width was up to $0.25 \mathrm{~mm}$. However, in some places along the weld root, the width was very small (almost zero), on the verge of a lack of penetration (Figure 1c).

The shape of the fusion zone (FZ) for all the beadon-plate welds, produced with the disk laser in the investigated range of the processing parameters clearly indicates that the welds were produced in the keyhole welding mode, characteristic for a high-power-density laser beam. In the case of a bead-on-plate weld produced at the minimum energy input $(100 \mathrm{~J} / \mathrm{mm})$, the $\mathrm{FZ}$ is columnar with almost parallel sidewalls and the $\mathrm{depth} /$ width ratio is 3.5 . A further reduction in the speed
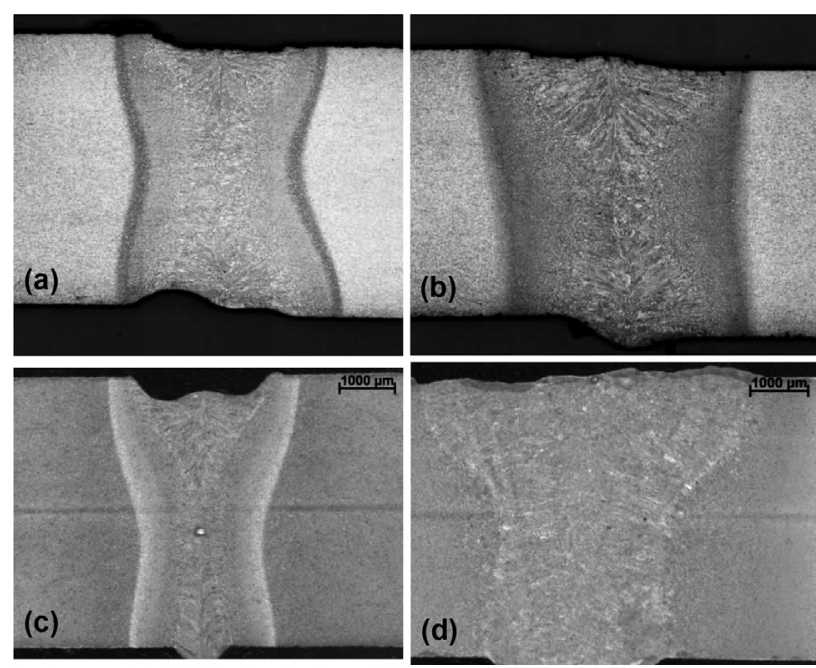

Figure 1: Optical micrographs of the 5.0-mm-thick butt joints of STRENX $1100 \mathrm{MC}$ steel produced with autogenous laser welding: a) at $3.3 \mathrm{~kW}, 1.5 \mathrm{~m} / \mathrm{min}$, energy input of $132 \mathrm{~J} / \mathrm{mm}$ (joint $\mathrm{A}$ ), b) at 3.3 $\mathrm{kW}, 1.0 \mathrm{~m} / \mathrm{min}$, energy input of $198 \mathrm{~J} / \mathrm{mm}$ (joint B) and bead-on-plate welds produced at: c) $3.3 \mathrm{~kW}, 2.0 \mathrm{~m} / \mathrm{min}$, energy input of $99 \mathrm{~J} / \mathrm{mm}$, d) $3.3 \mathrm{~kW}, 0.5 \mathrm{~m} / \mathrm{min}$, energy input of $396 \mathrm{~J} / \mathrm{mm}$ of bead-on-plate welding at a constant value of the laser output power increased the width of the weld and the width of the heat-affected zone (HAZ) due to the increased energy input. For example, the face width of a bead-on-plate weld produced at the maximum energy input of $396 \mathrm{~J} / \mathrm{mm}$ was very wide, over $6.0 \mathrm{~mm}$ (Figure 1d). It obviously indicates that the energy input was too high for the bead-on-plate laser welding of 5.0-mmthick butt joints. Additionally, the HAZ width was very wide, over $1.5 \mathrm{~mm}$ (each side), indicating intensive heating and relatively slow cooling rates, which may lead to harmful structural transformations. It should also be noted that no cracks were found in the regions of the weld metal, or in the heat-affected zones. Based on the results obtained during the preliminary test of bead-onplate laser welding, the welding speeds of $1.0 \mathrm{~m} / \mathrm{min}$ and $1.5 \mathrm{~m} / \mathrm{min}$ were considered as the optimum values at the laser output power of $3.3 \mathrm{~kW}$, and thus energy inputs of $132 \mathrm{~J} / \mathrm{mm}$ and $198 \mathrm{~J} / \mathrm{mm}$, respectively, were chosen for the laser welding of butt joints for the subsequent mechanical examinations.

Direct observations, visual inspections (VT) and macrograph examinations of the test butt joints showed proper shapes of the weld face, the root and the FZ in the case of test joint B, laser welded at $1.0 \mathrm{~mm} / \mathrm{min}$ and at a laser power of $3.3 \mathrm{~kW}$, thus using the energy input of 198 $\mathrm{J} / \mathrm{mm}$ (Figure 1b). The weld face and the root were very flat and even with proper reinforcements, which prove a high quality of such types of butt joints. For comparison, test joint $\mathrm{A}$, welded at a slightly lower energy input of $132 \mathrm{~J} / \mathrm{mm}$ (a laser power of $3.3 \mathrm{~kW}$, a welding speed of $1.5 \mathrm{~m} / \mathrm{min}$ ), showed undercuts of the root and a slight collapse of the weld face, as can be seen in Figure 1a. The shapes of the FZs of both test welds were appropriate, exhibiting $\mathrm{X}$ configurations, the so-called hourglass configurations (Figure 1). Such a shape of the fusion zone during butt-joint welding with a laser beam is also typical for the keyhole-mode (deep penetration) welding. The depth/width ratio measured for test joint A was 1.9 and in the case of test joint B it was approx. 1.15. Examinations of the macrographs showed no internal imperfections of the two test butt joints.

\subsection{Microhardness and mechanical examinations}

The microhardness was measured on the cross-sections of the test butt joints. Based on the results, the microhardness profiles were determined (Figure 2). As can be seen in Figure 2, a sharp drop in the microhardness occurs in the HAZ region adjacent to the fusion zone, while the microhardness of the base material of the STRENX 1100 steel is in a range of 400-450 HV0.2 (Figure 2). The minimum value of the microhardness determined in the HAZ was a bit below 300 HV0.2, while the microhardness in the fusion zone (the weld metal) was stable and in the range 400-450 HV 0.2. 

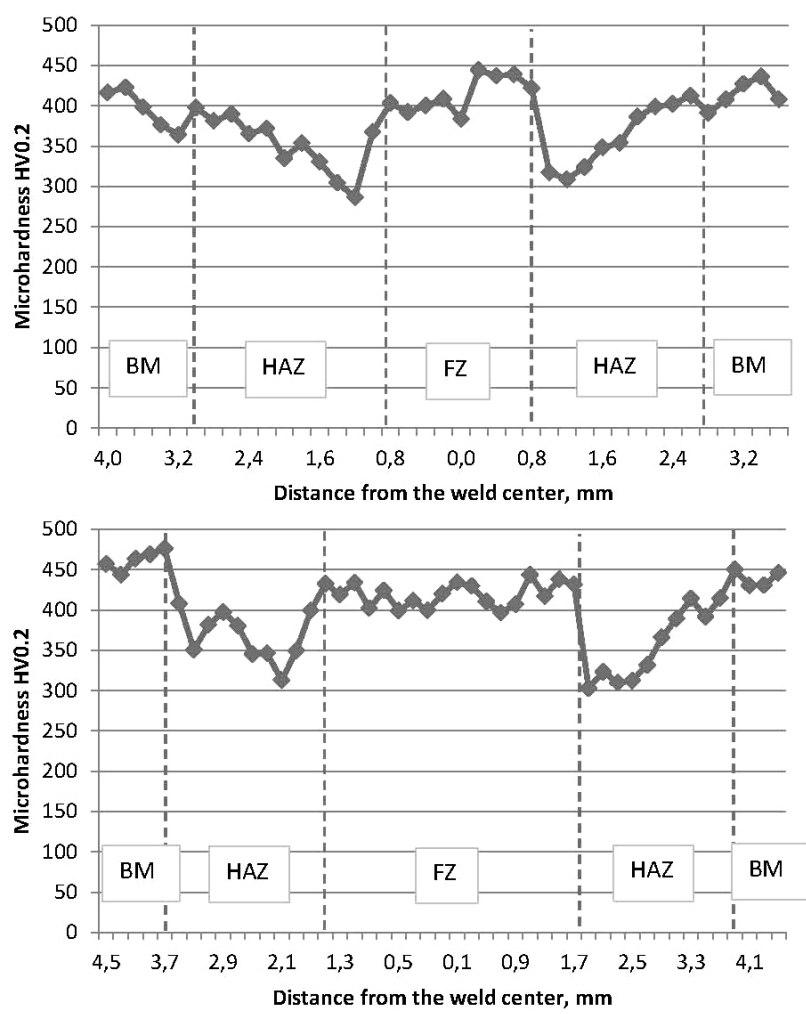

Figure 2: Microhardness profiles at the cross-sections of the 5.0-mm-thick butt joints of STRENX $1100 \mathrm{MC}$ steel welded with a disk laser: a) joint A (energy input of $132 \mathrm{~J} / \mathrm{mm}$ ), b) joint B (energy input of $198 \mathrm{~J} / \mathrm{mm}$ )

The technological bending tests exhibited a limited plasticity of the test butt joints due to a low angle of the bending, being in the range $85-90^{\circ}$ for both test joints. On the other hand, the results of the static tensile tests showed that the tensile strength of the test joints is just slightly lower, compared to the strength of the base material (BM) of the STRENX 1100MC steel. The tensile strength for both tested joints was in a range of 1192-1295 MPa, while the tensile strength of the BM was 1324-1340 MPa. In all the tensile samples of the butt joints, fracture occurred in the weld metal. The reason for a lower tensile strength of the test joints in comparison to the $\mathrm{BM}$ is a decrease in the microhardness of the HAZ adjacent directly to the FZ, as shown in Figure 2.

The Charpy V-notch test, conducted at room temperature, showed that the impact toughness of the test butt joints is significantly lower than the impact toughness of the STRENX 1100MC steel. The experimentally determined impact toughness of the base material was in a very narrow range of $141-143 \mathrm{~J} / \mathrm{cm}^{2}$, while the impact toughness of test butt joint A, welded at the lower energy input of $132 \mathrm{~J} / \mathrm{mm}$ (the laser power of $3.3 \mathrm{~kW}$, the welding speed of $1.5 \mathrm{~m} / \mathrm{min}$ ) was just $57.9-78 \mathrm{~J} / \mathrm{cm}^{2}$, having the mean value of $70.6 \mathrm{~J} / \mathrm{cm}^{2}$. As can be easily calculated, the impact toughness accounts for only $50 \%$ of that for the BM. On the other hand, the impact toughness of test joint $\mathrm{B}$, welded at the higher energy input of $198 \mathrm{~J} / \mathrm{mm}$ (the laser power of $3.3 \mathrm{~kW}$, the welding speed of $1.0 \mathrm{~m} / \mathrm{min}$ ) was slightly higher, $86.13 \mathrm{~J} / \mathrm{cm}^{2}$, so about $60.6 \%$ of the impact toughness of the BM.

SEM micrographs of the fracture surfaces of the test joints are presented in Figures $\mathbf{3}$ and $\mathbf{4}$. As can be seen, the fracture surfaces indicate a rather ductile dimple fracture mode in both cases (Figures 3 and 4). The impact toughness of the test joint welded at the higher energy input (joint B) is clearly higher, by about $22 \%$, compared to the impact toughness of the joint welded at the lower energy input (joint A). Additionally, the fracture surface of joint B exhibits a more ductile behaviour than the fracture surface of joint A (Figures 3a and 4a). Thus, the results indicate that the impact toughness of the butt joints depends on the energy input of laser welding, thus on the thermal conditions, cooling rates and structure of the weld metal and the HAZ. However, high-magnification SEM micrographs of the fracture surfaces revealed discontinuities across the surfaces of both test joints, such as small pores (Figures $\mathbf{3 b}$ and $\mathbf{4 b}$ ). Inside the spherical discontinuities, inclusions were found.

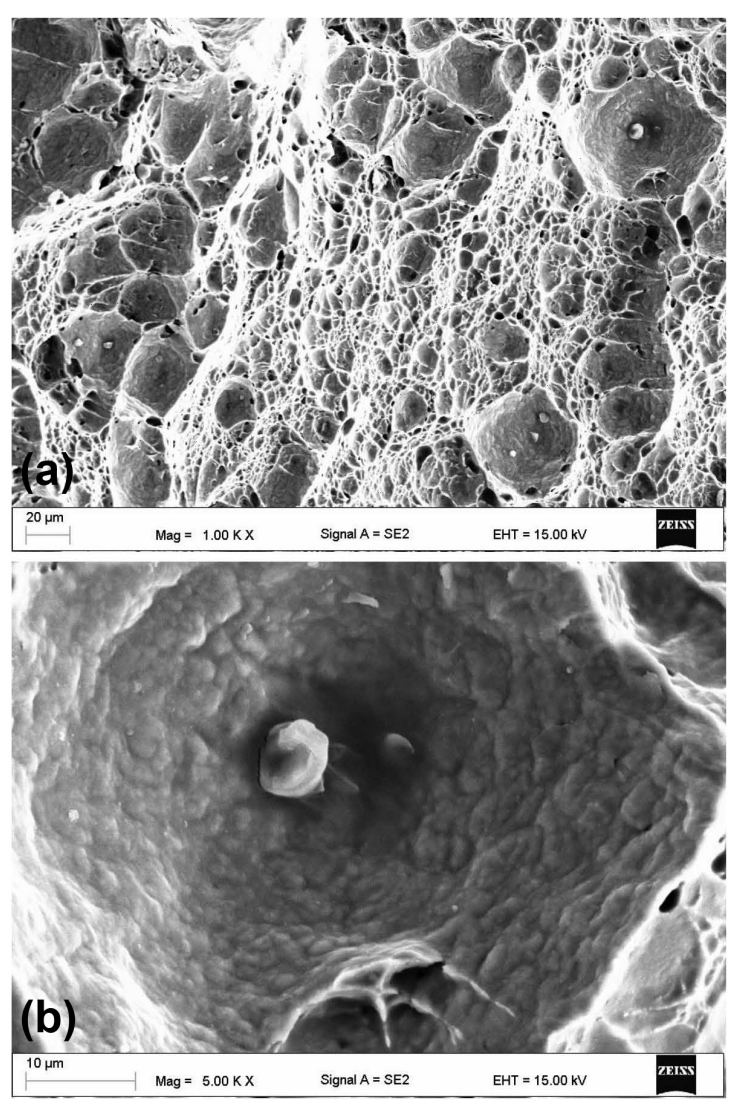

Figure 3: SEM micrographs of the fracture surface of test joint A (energy input of $132 \mathrm{~J} / \mathrm{mm}$ ) after the impact test of the joints: a) general view of the fracture surface, b) an inclusion placed in the material discontinuity 


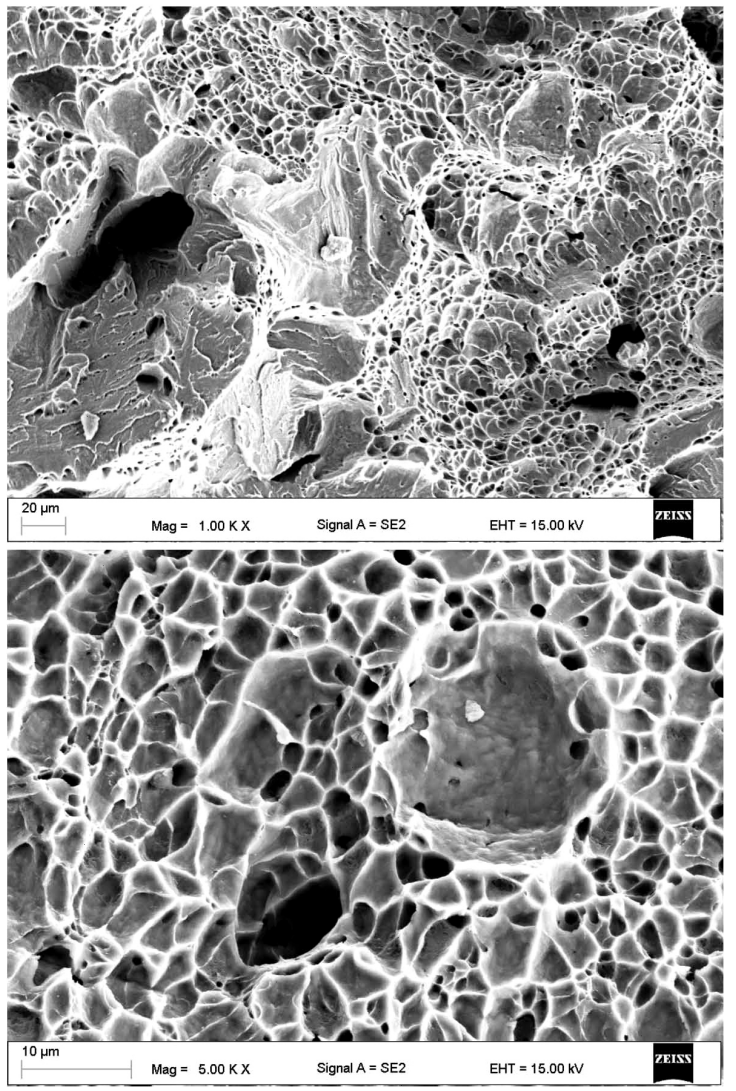

Figure 4: SEM micrographs of the fracture surface of test joint $B$ (energy input of $198 \mathrm{~J} / \mathrm{mm}$ ) after the impact test of the joints: a) general view of the fracture surface, b) an inclusion placed in the material discontinuity

The EDS spectrum of an inclusion showed mainly iron $(98.47 \% \mathrm{Fe}$ of mass fraction) and a small content of chromium $(1.53 \% \mathrm{Cr}$ of mass fraction), as shown in Figure 5b. No traces of oxides were found. It indicates that the inclusions are rather metallic and a proper shielding-gas atmosphere was provided during the laser-welding tests. Thus, the micropores revealed during the examinations of the fracture surface are a result of the metal vapours produced during intensive heating of the liquid metal of the weld pool by the focused laser beam at a high intensity and during keyhole-mode welding, as reported by other researches. ${ }^{1,17}$

\subsection{Microstructure examinations}

In order to determine the microstructures of the weld metal and HAZ, the chemical composition of the base material was analyzed with the GDS method and the cooling times $t_{8 / 5}$ in a temperature range of $800-500{ }^{\circ} \mathrm{C}$ were calculated according to the procedure described in reference ${ }^{17}$. The cooling time $t_{8 / 5}$ calculated for the energy input of $198 \mathrm{~J} / \mathrm{mm}$ of laser welding was below $1.3 \mathrm{~s}$. The cooling time $t_{8 / 5}$ for the energy input of $132 \mathrm{~J} / \mathrm{mm}$ was below $0.6 \mathrm{~s}$. It must be noted that the cooling times are significantly shorter than the cooling times recommended for the typical quenched and tem-
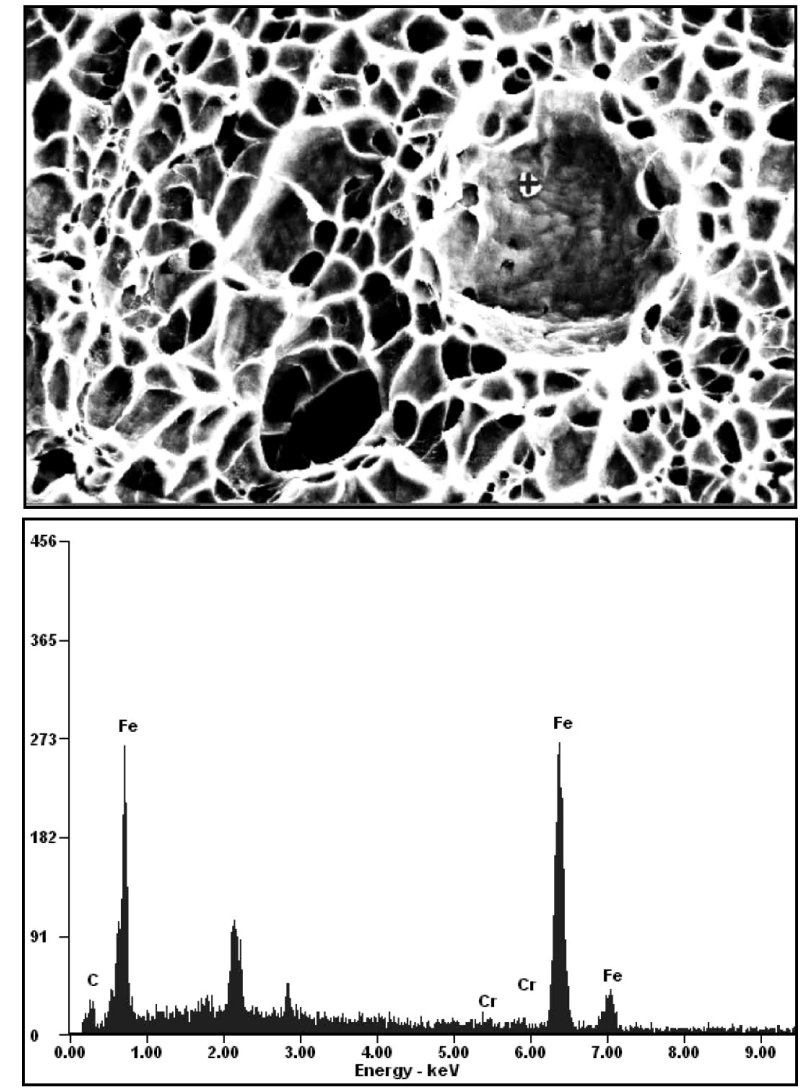

Figure 5: a) SEM micrograph of the fracture surface of test joint B (energy input of $198 \mathrm{~J} / \mathrm{mm}$ ) after the impact test of the joints and b) EDS spectrum of the inclusion in the spherical discontinuity

pered steel grades, which are in the range 5-15 s. Despite such short cooling times, the joints showed no tendency to cold cracking.

A detailed analysis of the chemical composition obtained with GDS showed that the investigated melt of the steel contains $0.139 \% \mathrm{C}, 0.31 \% \mathrm{Si}, 1.40 \% \mathrm{Mn}, 0.7 \% \mathrm{Cr}$, $0.3 \% \mathrm{Ni}, 0.06 \% \mathrm{Mo}, 0.039 \% \mathrm{Al}, 0.01 \%$ of both $\mathrm{Ti}$ and $\mathrm{Cu}$, $0.006 \% \mathrm{~V}$ and $0.001 \% \mathrm{Nb}$

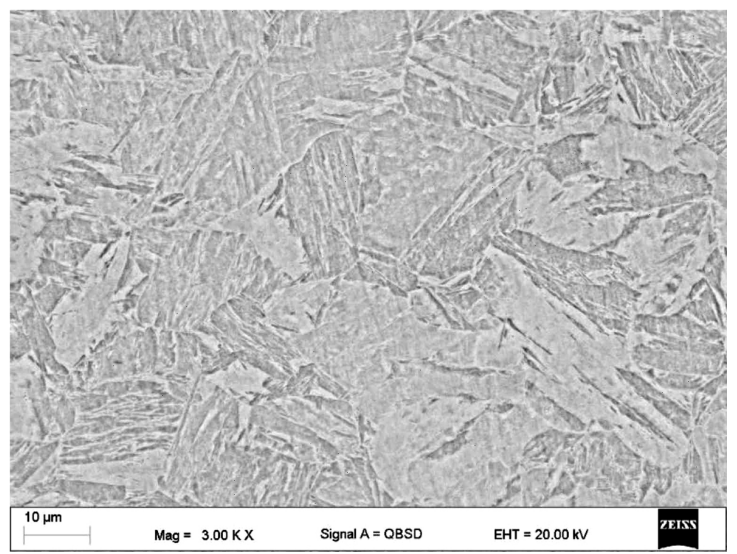

Figure 6: SEM micrograph of the base material STRENX 1100MC steel 

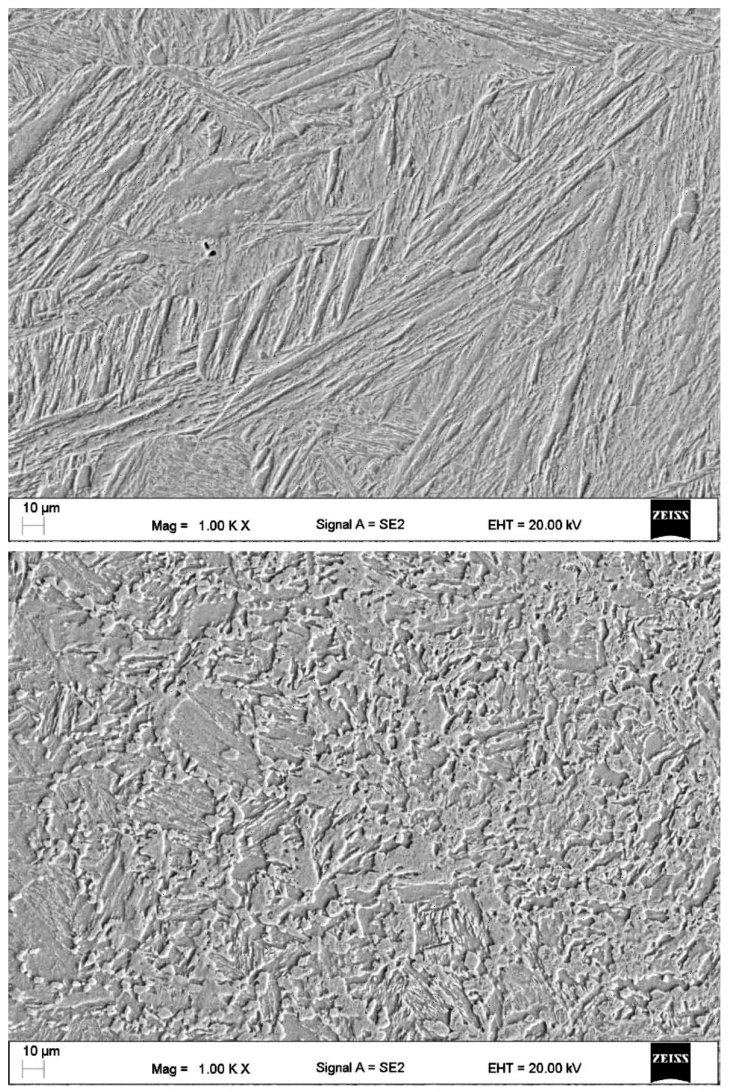

Figure 7: SEM micrographs of test butt joint A welded at the energy input of $132 \mathrm{~J} / \mathrm{mm}$ (cooling time $t_{8 / 5}$ of $0.6 \mathrm{~s}$ ): a) weld metal, b) HAZ region

Based on the determined chemical composition, the martensitic-transformation temperature Ms and carbon equivalent $\mathrm{CET}$ were calculated according to the procedure described in details in ${ }^{28}$. The calculated $\mathrm{Ms}$ temperature was $430.6{ }^{\circ} \mathrm{C}$, while the carbon equivalent CET was just 0.328 . The determined high Ms temperature and relatively low carbon equivalent, in relation to the high strength of the investigated steel, indicate that the hardenability of the steel is not very high.

SEM micrographs of the base material showed that the STRENX 1100MC steel is composed of a finegrained bainitic-martensitic structure with a significant proportion of acicular ferrite and also traces of retained austenite (Figure 6). Additionally, precipitations of small carbides with a high dispersion can be identified in the structure. The structures of the weld metal and the HAZ of test butt joints are shown in Figures 7 and 8 . It is clear that the structures and morphologies of the phase constituents in the weld metal depend on the energy input of laser welding. In general, the structure of the weld metal consists mainly of bainite, plate martensite, fine martensitic islands and also ferrite, mainly polygonal $\left(\alpha_{\mathrm{pf}}\right)$ and allotriomorphic ferrite $\left(\alpha_{\mathrm{af}}\right)$ (Figures 7 and 8).

As can be seen, the fraction (share) of plate martensite in the weld metal of test joint $\mathrm{A}$, produced at the
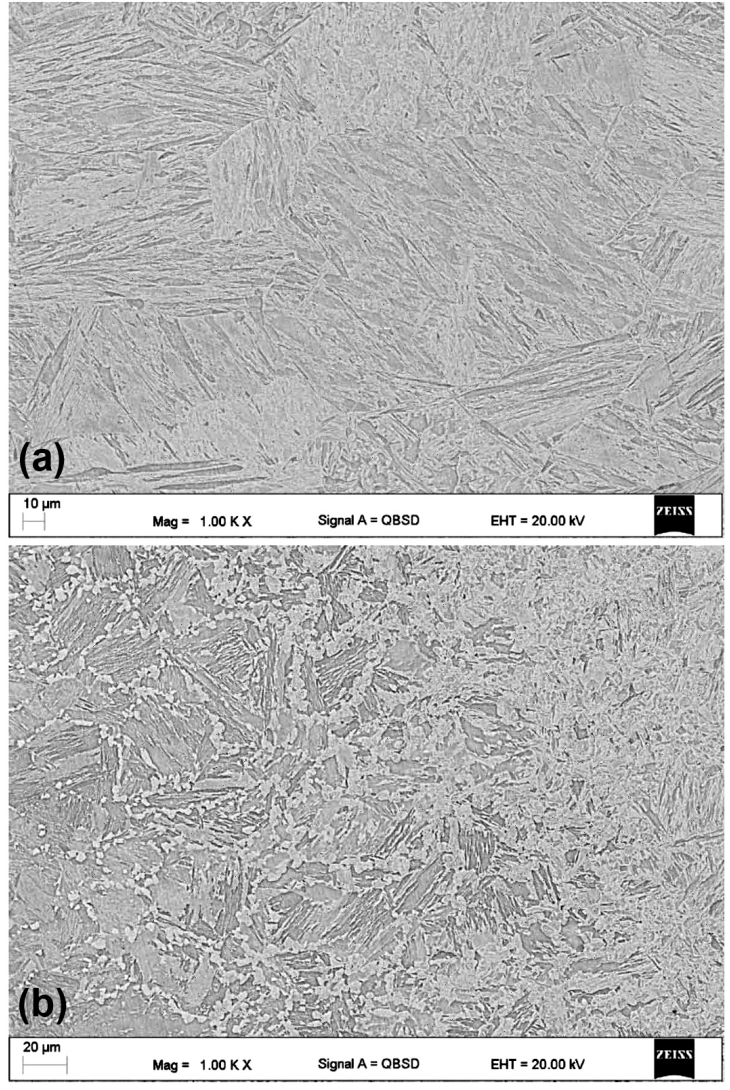

Figure 8: SEM micrographs of test butt joint B welded at the energy input of $198 \mathrm{~J} / \mathrm{mm}$ (cooling time $t_{8 / 5}$ of $1.3 \mathrm{~s}$ ): a) weld metal, b) HAZ region

energy input of $132 \mathrm{~J} / \mathrm{mm}$ (the laser power of $3.3 \mathrm{~kW}$, the welding speed of $1.5 \mathrm{~m} / \mathrm{min}$ ) is approx. $20 \%$ higher (calculated with planimetric measurements on the micrographs) compared to the weld metal of joint $\mathrm{B}$, produced at $198 \mathrm{~J} / \mathrm{mm}$ (the laser power of $3.3 \mathrm{~kW}$, the welding speed of $1.0 \mathrm{~m} / \mathrm{min}$ ). Actually, plate martensite is the dominant structure of the weld metal of joint $\mathrm{A}$, while the structure of the weld metal of joint B is more similar to the structure of the base material of STRENX $1100 \mathrm{MC}$ (Figures 6, 7 and 8). In this case, the structure is more diverse with a higher fraction of fine martensitic islands (acicular martensite). In summary, the share of the plate and acicular martensite had the greatest effect on the properties of the test joints, especially on the impact toughness. Cooling rates that are too high during the laser welding of the 5.0-mm-thick butt joints of the STRENX 1100MC steel lead to an increase in the plate martensite and thus a decrease in the toughness.

\section{CONCLUSIONS}

The obtained results of the laser welding of the STRENX 1100MC steel showed that it is possible to produce butt joints characterized by a proper shape, flat and even faces and roots, and free of any significant structural imperfections. The investigated high-strength 


\section{MATERIALI IN TEHNOLOGIJE/MATERIALS AND TECHNOLOGY (1967-2017) - 50 LET/50 YEARS}

\section{A. KURC-LISIECKA: IMPACT TOUGHNESS OF LASER-WELDED BUTT JOINTS OF THE NEW STEEL GRADE STRENX 1100MC}

steel is characterized by a small amount of alloying elements, surprisingly low carbon equivalent CET, just 0.328 , and, simultaneously, a high temperature of martensitic transformation Ms, about $430.6^{\circ} \mathrm{C}$. Despite the low carbon equivalent, the base metal has a fine-grained bainitic-martensitic structure with a high microhardness, 400-450 HV0.2. Despite a very rapid solidification of the weld metal and rapid cooling rates, no tendency to cracking of the weld metal or HAZ was found. A significant drop in the microhardness was revealed in the $\mathrm{HAZ}$, resulting in the breaking of the samples during the tensile tests.

The differences in the impact toughness of the test joints are related to the share of the plate and acicular martensite in the weld metal of the tests joints. Cooling rates that are too high during the laser welding of the 5.0-mm-thick butt joints of the STRENX 1100MC steel are unfavourable because they lead to an increase in the plate martensite, which, in turn, decreases the toughness of the weld metal.

\section{REFERENCES}

${ }^{1}$ A. Lisiecki, Effect of heat input during disk laser bead-on-plate welding of thermomechanically rolled steel on penetration characteristics and porosity formation in the weld metal, Arch. Metall. Mater., 61 (2016) 1, 93-102, doi:10.1515/amm-2016-0019

${ }^{2}$ A. Kurc-Lisiecka, W. Ozgowicz, W. Ratuszek, J. Kowalska, Analysis of deformation texture in AISI 304 steel sheets, Sol. St. Phenom., 203-204 (2013), 105-110, doi:10.4028/www.scientific.net/SSP.203204.105

${ }^{3}$ A. Lisiecki, Diode laser welding of high yield steel, Proc. SPIE 8703, Laser Technology 2012: Applications of Lasers, 87030S (January 22, 2013), doi:10.1117/12.2013429; doi:10.1117/12. 2013429

${ }^{4}$ J. Górka, Weldability of thermomechanically treated steels having a high yield point, Arch. Metall. Mater., 60 (2015), 469-475

${ }^{5}$ A. Grajcar, M. Różański, S. Stano, A. Kowalski, Microstructure characterization of laser-welded Nb-microalloyed silicon-aluminum TRIP steel, J. Mater. Eng. Perform., 23 (2014), 3400-3406

${ }^{6}$ A. Lisiecki, Titanium matrix composite Ti/TiN produced by diode laser gas nitriding, Metals, 5 (2015), 54-69, doi:10.3390/ met5010054

${ }^{7}$ R. Burdzik, Ł. Konieczny, Z. Stanik, P. Folega, A. Smalcerz, A. Lisiecki, Analysis of impact of chosen parameters on the wear of camshaft, Arch. Metall. Mater., 59 (2014), 957-963, doi:10.2478/ amm-2014-0161

${ }^{8}$ J. Kusiński, S. Kac, A. Kopia, A. Radziszewska, M. Rozmus-Górnikowska, B. Major, L. Major, J. Marczak, A. Lisiecki, Laser modification of the materials surface layer - a review paper, Bull. Pol. Acad. Sci., Tech. Sci., 60 (2012), 711-728, doi:10.2478/ v10175-012-0083-9

${ }^{9}$ K. Janerka, M. Pawlyta, J. Jezierski, J. Szajnar, D. Bartocha, Carburiser properties transfer into the structure of melted cast iron, J. Mat. Proc. Tech., 214 (2014) 4, 794-801
${ }^{10}$ Ł. Konieczny, R. Burdzik, B. Łazarz, Application of the vibration test in the evaluation of the technical condition of shock absorbers built into the vehicle, J. Vibroeng, 15 (2013) 4, 2042-2048

${ }^{11}$ A. Czuprynski, J. Górka, M. Adamiak, Examining properties of arc sprayed nanostructured coatings, Metalurgija, 55 (2016) 2, 173-176

${ }^{12}$ L. A. Dobrzański, W. Sitek, M. Krupiński, J. Dobrzański, Computer aided method for evaluation of failure class of materials working in creep conditions, J. Mat. Proc. Tech., 157 (2004), 102-106

${ }^{13}$ J. Bodzenta, A. Kaźmierczak, T. Kruczek, Analysis of thermograms based on FFT algorithm, J. Phys. IV, 129 (2005), 201-206

${ }^{14} \mathrm{G}$. Moskal, A. Grabowski, A. Lisiecki, Laser remelting of silicide coatings on Mo and TZM alloy, Sol. St. Phenom., 226 (2015), 121-126, doi:10.4028/www.scientific.net/SSP.226.121

${ }^{15}$ A. Lisiecki, Welding of thermomechanically rolled steel by Yb:Yag disk laser, Arch. Metall. Mater., 60 (2015), 2851-2859, doi:10.1515/ amm-2015-0456

${ }^{16}$ A. Lisiecki, R. Burdzik, G. Siwiec, Ł. Konieczny, J. Warczek, P. Folęga, B. Oleksiak, Disk laser welding of car body zinc coated steel sheets, Arch. Metall. Mater., 60 (2015), 2913-2922, doi:10.1515/ amm-2015-0465

${ }^{17}$ A. Lisiecki, Welding of thermomechanically rolled fine-grain steel by different types of lasers, Arch. Metall. Mater., 59 (2014), 1625-1631, doi:10.2478/amm-2014-0276

${ }^{18}$ R. Burdzik, T. Węgrzyn, Ł. Konieczny, A. Lisiecki, Research on influence of fatigue metal damage of the inner race of bearing on vibration in different frequencies, Arch. Metall. Mater., 59 (2014), 1275-1281, doi:10.2478/amm-2014-0218

${ }^{19}$ M. Staszuk, L. A. Dobrzański, T. Tański, W. Kwaśny, M. Musztyfaga-Staszuk, The effect of PVD and CVD coating structures on the durability of sintered cutting edges, Arch. Metall. Mater., 59 (2014), 269-274

${ }^{20}$ T. Węgrzyn, J. Piwnik, D. Hadryś, R. Wieszała, Car body welding with micro-jet cooling, J. Arch. Mater. Sci. Eng., 49 (2011), 90-94

${ }^{21}$ A. Grajcar, M. Różański, S. Stano, A. Kowalski, B. Grzegorczyk, Effect of heat input on microstructure and hardness distribution of laser welded Si-Al TRIP-type steel, Adv. Mater. Sci. Eng., 2014 (2014), doi:10.1155/2014/658947

${ }^{22}$ A. Lisiecki, Welding of titanium alloy by disk laser, Proc. SPIE 8703, Laser Technology 2012: Applications of Lasers, 87030T (January 22, 2013), doi:10.1117/12.2013431; doi:10.1117/12. 2013431

${ }^{23} \mathrm{~J}$. Słania, Influence of phase transformations in the temperature ranges of $1250-1000{ }^{\circ} \mathrm{C}$ and $650-350{ }^{\circ} \mathrm{C}$ on the ferrite content in austenitic welds made with T 2312 LRM3 tubular electrode, Arch. Metall. Mater., 50 (2005), 757-767

${ }^{24}$ D. Janicki, Disk laser welding of armor steel, Arch. Metall. Mater., 59 (2014), 1641-1646, doi:10.2478/amm-2014-0279

${ }^{25}$ B. Slazak, J. Słania, T. Węgrzyn, A. P. Silva, Process stability evaluation of manual metal arc welding using digital signals, Mater. Sci. Forum, 730-732 (2013), 847-852

${ }^{26}$ W. Pakieła, T. Tański, Z. Brytan, K. Labisz, The influence of laser alloying on the structure and mechanical properties of AlMg5Si2Mn surface layers, Appl. Phys. A, 122 (2016), 352, doi:10.1007/s00339016-9834-z

${ }^{27} \mathrm{M}$. Bonek, The investigation of microstructures and properties of high speed steel HS6-5-2-5 after laser alloying, Arch. Metall. Mater., 59 (2014), 1647-1651, doi:10.2478/amm-2014-0280 